\title{
Ida I Dewa Agung Istri Kania: RAJA, FEMINISME, DAN PAHLAWAN DARI KLUNGKUNG
}

\author{
Oleh: \\ I Nyoman Sukartha \\ Fakultas Ilmu Budaya UNUD Denpasar \\ e-mail: inyomansukartha@yahoo.co.id
}

\begin{abstract}
The feminism movement in the field of classical literature in Bali is known to rise after a female author struggling from the Dutch intervention. This female figure was Ida I Dewa Agung Istri Kania. She had compiled several literary works through her criticism and "lango", either herself or accompanied by her pupils. The forms of her works are kakawin, kidung, geguritan, and tutur. The most popular work is Kakawin Pralambang Bhasa Wewatekan. This Kakawin tells about death body burning ceremony (Patiwa-tiwa and Baligya). It describes the entrance of Dutch into Bali and the struggle to fight against in Kusamba, Klungkung. There is also a story concerning the memorandum of understanding between Klungkung, Gianyar, Bangli, and Payangan. These stories come along with several other stories behind some factual events made in Kusamba, Sweta Lombok, Tabanan, as well as in Klungkung.

It is very interesting that the phenomenal Ida I Dewa Agung Istri Kania is analyzed on the sociology of literature viewpoint. It is supposed to have significance for the younger and future generations, at least in Bali. The Balinese society must be proud of having their own hero, King, who is an author of the classical works. She is a mirror, figure to take as an example of nobleness for the nation, particularly the younger female generations.
\end{abstract}

Keywords: feminist, King and Hero

\begin{abstract}
Abstrak
Paham pergerakan perempuan dalam dunia sastra klasik di Bali dikenal dengan munculnya seorang pengarang wanita yang sekaligus merupakan pejuang dalam melawan intervensi Belanda. Tokoh yang dimaksud adalah Ida I Dewa Agung Istri Kania. Lewat pikiran kritis dan "langõ" beliau lahir beberapa karya, baik karya sendiri maupun karya bersama dengan murid beliau. Karya-karya beliau berupa kakawin, kidung, geguritan dan tutur. Salah satu karya beliau yang terkenal adalah Kakawin Pralambang Bhasa Wewatekan. Kakawin itu menceritakan tentang: upacara pembakaran mayat (Patiwa-tiwa dan Baligya), gambaran kedatangan dan perang melawan Belanda di Kusamba Klungkung, sumpah kesepakatan kerjasama antara Klungkung, Gianyar, Bangli, dan Payangan, dan masih ada lagi beberapa kisah faktual yang terjadi baik di Kusamba, di Sweta Lombok, di Tabanan, dan di Klungkung.

Menariknya kepengarangan Ida I Dewa Agung Istri Kania dikaji berdasarkan sosiologi sastra, tentu sangat bermanfaat bagi generasi kini dan mendatang, setidaknya dalam lingkup Bali. Masyarakat Bali akan lebih merasa bangga memiliki seorang pahlawan, raja, yang sekaligus berprofesi sebagai pujangga klasik. Beliau merupakan sosok cermin, panutan atau suri tauladan anak bangsa khususnya generasi muda wanita Bali.
\end{abstract}

Kata kunci: feminis, Raja dan Pahlawan 


\section{PENDAHULUAN}

Feminisme merupakan sebuah paham tentang pergerakan perempuan yang di dalam dunia teori sastra (teori postmodern) boleh dibilang baru. Tahun 1960-an, walau bukan awal mula lahirnya teori feminisme dalam dunia sastra, dapat dikatakan baru kedapatan pergerakan yang lebih bersifat pembaharuan mengenai tradisi pemikiran kaum wanita yang bersifat sastrawi. Maksudnya adalah pembaharuan tradisi pemikiran dan tindakan lama yang sudah memiliki buku-buku klasiknya sendiri, yang mendiagnosis masalah ketidaksetaraan posisi perempuan dalam masyarakat beserta solusi yang diusulkan (Barry, 2010;141).

Lebih jauh dikatakan bahwa pergerakan perempuan pada tahun 1960-an inilah yang mengakibatkan lahirnya kritik sastra feminis pada masa kini. Kaum perempuan menyadari signifikansi citra perempuan yang disebarluaskan oleh sastra dan memandang penting sekali untuk melawan hal itu dan mempertanyakan otoritas serta koherensinya. Berlanjut pada tahun 1970an, kritik feminis ditujukan pada upaya pembedahan mengenai mekanisme patriarki. Artinya adalah kultur berfikir laki-laki dan perempuan yang mengajegkan ketidaksetaraan seksual. Tentu saja lebih ditekankan pada pandangan penulis laki-laki yang mengkondisikan perempuan sebagai obyek. Mereka mengonstruksi citra perempuan yang banyak berpengaruh pada karyanya. Kenyataan ini boleh dibilang bahwa kaum perempuan "siap perang" dan polemis (Barry, 2010;143).

Deskripsi di atas menyatakan bahwa, pada era 1980-an kritik feminisme lebih dinamis. Kritik feminis semakin jauh lebih ekletik dari era sebelumnya. Pusat perhatiannya dialihkan dari menyerang laki-laki atas dunianya menjadi penyelidikan ciri-ciri dunia, dan sudut pandang perempuan. Di sisi lain juga merekonstruksi tulisan-tulisan tentang pengalaman wanita yang ditekan/direndahkan bahkan dihilangkan. Fokus perhatiannya juga dialihkan pada kepentingan mengonstruksi kanon tulisan wanita dengan menulis ulang, sehingga peran wanita yang semula hilang dan ditekan menjadi semakin ditonjolkan/diutamakan. Adanya perubahan fokus perhatian itu menyebabkan terjadinya pergeseran sudut pandang. Pergeseran fokus perhatian yang dimaksud adalah, dari "an- droteks" (buku karya laki-laki) ke "ginoteks" (buku karya perempuan).

Feminisme berbeda dengan emansipasi. Sugihastuti dan I. H.Saptiawan, (2007: 95) mengatakan bahwa emansipasi lebih menekankan pada partisipasi perempuan dalam pembangunan tanpa mempersoalkan hak serta kepentingan mereka yang dinilai tidak adil, sedangkan feminisme dimaksudkan sebagai aktivitas dan inisiatif wanita itu sendiri dalam menggunakan hak dan kepentingan dalam berbagai gerakan.

Susanto mengatakan bahwa feminisme merupakan gerakan sosial atau perubahan yang bersifat politis dan ideologis $(2015 ; 248)$. Nyoman Kuta Ratna $(2005 ; 226)$ mengatakan bahwa feminis berasal dari kata femme yang berarti 'wanita'. Feminis diartikan sebagai 'posisi politis'. Sedang feminim berarti perempuan secara biologis.

Bertolak dari pendapat di atas maka dapat dikatakan bahwa feminisme berarti paham perempuan atau "suatu aliran dalam dunia sastra". Feminisme ini berhubungan dengan studi tentang konsep kritik sastra feminis, yaitu studi sastra yang memfokuskan analisisnya pada perempuan. Jadi, berupa kajian sosial yang melibatkan kelompok-kelompok perempuan yang merasa termarginalkan dan tertindas oleh budaya patriarchi. Namun demikian feminisme bukanlan berarti sebuah pemberontakan perempuan terhadap laki-laki. Bukan upaya merevolusi pranata-pranata sosial, budaya seperti perkawinan, rumah tangga, maupun bidang public. Yang jelas bahwa kaum perempuan pada dasarnya tidak mau dimarginalkan atau dinomerduakan.

Suwardi Endraswara (2008; 146) mengatakan bahwa sasaran studi feminisme berhubungan dengan: (1) karya-karya tulis wanita masa lalu dan masa kini, (2) mengungkap berbagai tekanan pada tokoh wanita, (3) berisikan ideologi pengarang wanita dan pria, (4) memuat tentang kajian aspek ginokritik, memahami proses kreatif kaum feminis, dan (5) berisikan tentang psikoanalisis feminis, mengapa wanita lebih menyenangi hal-hal yang halus, emosional, kasih sayang dan sebagainya. Jadi, kritik sastra feminis adalah studi sastra yang mengarahkan focus analisisnya pada perempuan (Wiyatmi, 2006; 113). Atau gerakan persamaan antara laki-laki dan perempuan di segala bidang. Terlepas dari pendapat pro dan kontra terhadap teori 
feminisme, dalam tulisan ini akan dicoba mengkaji feminisme abad ke-19 yang ada di Bali khususnya di kerajaan Klungkung.

\section{PEMBAHASAN}

\subsection{Sekilas Tentang Ida Dewa Agung Istri Kania}

Kisah Dewa Agung Istri Kania sangat jarang diketahui oleh masyarakat. Hal ini disebabkan oleh sangat minimnya data-data sejarah yang bisa ditemukan yang mengungkap riwayat hidup beliau. Kemungkinan lain, juga disebabkan oleh politik penjajah Belanda yang sengaja menghilangkan atau pun mengaburkan data-data sejarah (Erniati, 1981: 20). Di sisi lain kemungkinan karena pada zaman itu belum ada kemauan dan alat untuk mendokumentasikan suatu peristiwa yang dianggap penting. Oleh karena itulah kisah hidup Ida Dewa Agung Istri Kania akan diungkap secara seadanya sesuai dengan yang ditemukan dalam beberapa pustaka.

Dewa Agung Istri Kania sering juga disebut Anak Agung Istri Kania. Beliau adalah salah satu keturunan (warih) dari Raja Sri Kresna Kepakisan, yang merupakan raja Samprangan, dan cikal bakal adanya keturunan Kepakisan di Bali. Beliau adalah putri dari Ida Dewa Agung Putra yang menjadi raja bawahan di daerah Kusamba (sekarang menjadi desa Kusamba yang berada di wilayah Kecamatan Dawan). Raja Klungkung pada waktu itu adalah Ida I Dewa Agung Sakti.

Nama Ida Dewa Agung Istri Kania atau Ida Anak Agung Istri Kania adalah nama gelar beliau setelah beliau menjadi raja. Sedang nama kecilnya adalah Dewa Agung Istri Muter. Dewa Agung Istri Muter semasa kecilnya tinggal di Kusamba, diasuh oleh ibu kandungnya yang bernama I Gusti Ayu Karang (anak raja Karangasem). Setelah beliau dewasa barulah beliau pindah ke Klungkung di asuh oleh kekaknya yaitu raja Klungkung yang bernama Ida I Dewa Agung Sakti. Istana beliau disebut Puri Bale Mas.

Setelah raja Ida I Dewa Agung Sakti (17251750) wafat, pemerintahannya digantikan oleh putra beliau yaitu Ida Dewa Agung Putra Kusamba (1785-1800) sebagai raja ke-VI pada tahun 1849. Beliau adalah ayah dari Dewa Agung Istri Muter (Putra.2015; lampiran silsilah). Namun segala urusan kepemerintahan di Klungkung sebagai pusat kerajaan, diserahkan kepada putrinya yaitu Dewa Agung Istri Muter. Dewa Agung
Putra Kusamba hanya mengurusi hal-hal yang berkaitan dengan kerajaan Kusamba saja. Setelah raja Dewa Agung Putra wafat maka beliau digantikan oleh putrinya yaitu Ida Idewa Agung Istri Muter. Setelah menjadi raja maka Idewa Agung Istri Muter lebih dikenal dengan nama Ida Dewa Agung Istri Kania. Beliau wafat tahun 1868. Sebelum beliau wafat beliau digantikan oleh sepupu nya yang bernama Ida Dewa Agung Putra III pada tahun 1851-1905.

\subsection{Kepahlawanan/Politik Sebagai Unsur Feminisme}

Seperti telah digambarkan pada uraian sebelumnya, bahwa Ida Dewa Agung Istri Kania adalah raja Kerajaan Klungkung ke VIII (18141868 wikipidea). Raja adalah jabatan politis yang menempatkan seseorang pada posisi puncak/tertinggi dari sebuah pemerintahan. Posisi tertinggi itu diduduki oleh Ida Dewa Agung Istri Kania yang kala itu masih muda/gadis.

Ketika pemerintahan beliau, pada tahun 1849 Kerajaan Klungkung mengalami serangan atau intervensi militer Belanda di bawah pimpinan jenderal Miechels. Pada waktu itu belum ada wanita yang punya keberanian untuk berperang. Berperang adalah tugas laki-laki. Namun, Ida Dewa Agung Istri Kania memimpin perlawanan melawan Belanda. Ini berarti bahwa, ada jiwa heroik/patriotik pada beliau sebagai keturunan ksatria.

Lebih-lebih lagi dengan terbunuhnya top pimpinan Belanda Jenderal Miechels. Belanda yang menyerang Kerajaan Klungkung pada waktu itu bisa dikalahkan, sehingga pada tahun 1849 Kerajaan Klungkung tidak bisa dikuasai/ dijajah oleh Belanda. Kerajaan Klungkung baru bisa ditundukkan oleh Belanda pada tahun 1908, atau setelah 57 tahun kemudian. Itu berarti waktunya sangat jauh dari masa kepemimpinan beliau, atau bukan pada masa kepemerintahan beliau.

Bila jiwa patriotik Ida Dewa Agung Istri Kania dihubungkan dengan pandangan Toril Moi, maka dapat dikatakan bahwa Ida Dewa Agung Istri Kania adalah sosok yang tergolong feminis. Beliau adalah sosok perempuan Bali yang masih lajang. Beliau berjuang demi rakyat dan tanah airnya, yaitu Kerajaan Klungkung. Beliau dijuluki raja berkepala batu oleh Belanda, karena sangat kokoh memegang prinsip, dan tidak mau menyerah, atau terus-terusan mengadakan per- 
lawanan kepada Belanda. Prinsip beliau adalah, lebih baik mati dari pada menyerah dan dijajah oleh Belanda. Sebab menyerah berarti turunnya derajat kebangsawanan dan harga diri seorang raja.

\subsection{Rakawi dan Feminisme}

Rakawi merupakan istilah yang terbangun atas unsur leksem ra- dan kawi. Dalam bahasa Jawa Kuno, leksem $r a$ - terletak di depan kata benda yang menunjuk kategori orang dari derajat tertentu atau orang-orang yang ada hubungan kekerabatan dengan orang yang berderajat lebih tinggi (Zoetmulder, 2006: 897). Contohnya: raputu berarti 'beliau yang merupakan cucu terhormat', rakawi berarti 'beliau pengarang terhormat'.

Dewa Agung Istri Kania adalah seorang raja. Jadi beliau merupakan orang yang sangat dihormati, khususnya di Kerajaan Klungkung bahkan di seluruh Bali. Beliau juga merupakan raja yang memiliki jiwa seni khususnya seni susastra. Beliau melahirkan beberapa karya seperti: $\mathrm{Ka}$ kawin Pralambang Bhasa Wawatekan, Kakawin Irawāntaka, Kakawin Astika Yāna, Kakawin Brahmāndha Pûrana (karya bersama), Kakawin Șakra Prējaya. (karya bersama), Tutur Biksu Pungu, Bhaka Bûmi, dan Geguritan Dasa Panda$w a$. Bertolak dari adanya unsur orang terhormat atau berkedudukan tinggi, dan juga unsur pengarang maka dapat dikatakan bahwa Ida Dewa Agung Istri Kania adalah seorang Rakawi.

Sebagai Rakawi, beliau juga merupakan sosok tokoh yang berpendirian teguh untuk mempertahankan Kerajaan Klungkung dari intervensi Belanda. Sebagai seorang raja, beliau memiliki posisi politis. Lebih-lebih lagi adanya darah keturunan kesatria yang melahirkan sifat patriotism. Beliau berjuang mempertahankan jagat Klungkung dari intervensi Belanda. Hal ini membuktikan bahwa beliau memiliki sifat feminis, feminism dan feminisme.

\subsection{Karya-karya Dewa Agung Istri Kania.}

Dalam uraian di atas, telah disebutkan karyakarya Ida Dewa Agung Istri Kania seperti; $\mathrm{Ka}$ kawin Pralambang Bhasa Wawatekan (Kakawin Bhasa Wewatekan), Kakawin Irawāntaka, Kakawin Astika Yāna, Kakawin Brahmāndha Pûrana (karya bersama), Kakawin Șakŗa Prējaya. (karya bersama), Tutur Biksu Pungu, Bhaka Bûmi, dan Geguritan Dasa Pandawaya . Ada praduga bah- wa Kidung Wargasari (versi Ida ratu Saking luhur) juga karya beliau bersama muridnya ). Untuk jelasnya akan diuraikan secara garis besar beberapa dari karya beliau.

\section{(1). Kakawin Pralambang Bhasa Wawa- tekan.}

Kakawin ini dibagi ke dalam beberapa judul tulisan (episode), yang dilanjutkan dengan beberapa catatan dari murid beliau. Judul tulisan yang dimaksud seperti yang disebutkan di bawah ini.

a) Iti bhasa wawatekan patiwa-tiwan ida maharaja dewata ring Blahpane, 6 bait 'Ini catatan tentang upacara Patiwa-tiwan (upacara pembakaran mayat) baginda raja yang wafat di Belahpane' (Raja I Dewa Agung Putra I, 1800).

b) Iti bhasa wawatekan yudhane ring Tulamben 2 bait.

'Ini catatan tentang cerita peperangan di Tulamben'

c) Iti bhasa wawatekan larude ka Sidemen 1 bait.

'Ini catatan tentang pengungsian ke Sidemen'

d) Iti bhasa wawatekan amuke ring puri Kusamba 3 bait.

'Ini catatan tentang pengamukan/kerusuhan di puri Kusamba'

e) Iki bhasa wawatekan yudhane ring Sakra 14 bait.

'Ini kisah tentang peperangan di Sakra'

f) Iti bhasa wawatekan padewasaksian padewagaman Klungkung, Gianyar, Bangli, Payangan, ring Panataran Agung ring Tegal Linggah, sareng padewasaksian Manguwi 25 bait

'Ini catatan mengenai perjanjian dan sumpah antara Klungkung, Gianyar, Bangli, Payangan, di pura Penataran Agung di Tegallinggah, bersama pula dengan penyumpahan Mengwi'.

g) Iti padewasaksian Ida Idewa Manggis 4 bait.

'Ini adalah catatan tentang penyumpahan dari I Dewa Manggis'.

h) Iti bhasa wawatekan I Gusti Gde Pamecutan 3 bait.

'Ini catatan tentang cerita I Gusti Pame- 
cutan'

i) Iti bhasa wawatekan panugtug padewasaksian I Dewa Manggis 2 bait.

'Ini catatan tentang penyumpahan lanjutan dari I Dewa Manggis'.

j) Iti bhasa wawatekan puun purine ring Tabanan 13 bait

'Ini catatan tentang kisah terbakarnya puri Tabanan'.

k) Iti bhasa wawatekan payudan agni manglawan toya 9 bait.

'Ini catatan tentang cerita perang api melawan air'.

1) Iti bhasa wawatekan dinan I Gusti Ngurah Made Agung mamras I Gusti Ketut Agung 19 bait.

'Ini catatan mengenai hari upacara pengangkatan anak yang bernama I Gusti Ketut Agung oleh I Gusti Ngurah Made Agung'

m) Iti bhasa wawatekan dinan puput purane ring Tamansari Tegallinggah 11 bait

'Ini catatan kisah mengenai hari selesainya pura Tamansari di Tegallinggah'.

n) Bhasa wawatekan Pamursita, Baligyane ring Kalungkung 1 dan 2 bait

'Catatan tentang pemujaan pada upacara Baligia (pembakaran mayat) di Klungkung'

o) Bhasa arêbadanâ, 3 bait.

'Cerita mengenai Arebadana'

p) Bhasa amateni warak, 2 bait

'Ceritera ketika membunuh badak'

q) Wawatekan Ida Anake Agung Ngurah

Made Karangasem, ndewata mayuda ring Sasak pamuke ring Sweta, 1 bait

'Ini ceritera wafatnya Ida Anak Agung Ngurah Made Karangasem yang berperang di Sasak (Lombok), waktu mengamuk di Sweta'.

r) Iti lelawasan rauh Blandane para $\mathrm{ka}$ Kalungkung. 6 bait.

'Ini gambaran ketika kedatangan Belanda ke Klungkung'

Selanjutnya adalah berupa keterangan dari pengarang lain (murid beliau yang bernama Anak Agung Pameregan) yang menjelaskan prihal kepengarangan Ida Dewa Agung Istri Kania.
Keterangan itu, dapat dilihat seperti di bawah ini. Pralambang iki, pakardin Idâ Dewati, Ida Dewa Agung Istri, putran Ida Maharaja Dewattha, Ida Dewagung Gde Putra, kang ndewata ring Belahpane aprang, masarengan ring pakardin Raja Dewata ring Loji.

\section{Terjemahan:}

Kakawin ini karya dari beliau yang telah tiada, beliau Ida Dewa Agung Istri Kania, putri dari almarhum Ida Dewa Agung Gede Putra I yang wafat di Belahpane bersama dengan karya almarhum yang wafat di Loji.

Kalimat di atas menandakan bahwa Bhasa Wewatekan yang merupakan bagian karya Dewa Agung Istri Kanya bersama ayah beliau telah berakhir. Pupuh selanjutnya merupakan karangan dari murid beliau kidung Rasmi Saňcaya, Edan Lelangon yang memakai pupuh Demung Tabeh Tiga. Kidung tersebut berjumlah 10 bait.

\section{Contoh bait ke 1, 10, dan 11.}

Katur ri jöng sang srining rūm-rum gita pracihnaning lara umunggw ing nilotphala tinambang ing kidung wasanti teleng ing sasih rari ngembanan ri padma sari panglinggan rarasmi sarimang amokung sandining sukraja swanita pinuput ri jero ning pūrnna śaśangka (bait 1)

Nahan raśmining nūsanya nglunging harsaning amarang kalangun amrih sūddhaning sâgara mwang wukir kunang yaning sama padohan muwuhi lara yan ketung kasaraning smarânganihana ri hati

mulat rumning sakalangwan lwirângatag twasing salulut (10)

sumbali posya nanggal I twas angarang ya ya ngarwaning akūng

kuru kurang ing tadah mwang nidra bhratâkingking hatur kung ing kagak inungkung

kuru nira kung tan polya amarani kung akung ing wini hi mawang kâkung ing kataman kung kinungkunging twas akung (11). 


\section{Terjemahan:}

Nyanyian ini dipersembahkan ke hadapan Dewi Intikeharuman, sebagai ungkapan duka cita yang ditulis di atas bunga teratai. Dinyanyikan dengan kidung musim semi, bersemayam di tengah bulan, dinda yang memangkunya, sebagai tanda remaja putrid yang sedang dilanda asmara, memendam cinta birahi yang berakhir pada bulan purnama (1)

Begitulah keindahan pulaunya yang membangkitkan rasa cinta pada orang yang mendatangi keindahan. Bermaksud mencari kesucian laut dan gunung bila sama-sama dilihat dari kejauhan. Hal itu yang menambah kesedihan bila dihitung rasa rindu asmara yang memanah hati, bila melihat wanginya segala yang indahindah, bagaikan membisiki perasaan cinta (10).

Kebetulan bulan Posya, saat penanggal (bulan terang), perasaan mengarang yang menyebabkan cinta. Badannya kurus sebab kurang makan dan tidur, menangis sedih, mengatakann cinta walau tiada dicinta, kurusnya karena cinta yang tidak mendapat balasan cinta kasih dari bini, menyebabkan sang pria yang terpanah asmara, diselimuti oleh rasa cinta kasih (11).

\section{(2) Kakawin Pralambang Bhasa Wawa- tekan adalah Kakawin unik.}

Kakawin adalah karya sastra yang berbentuk puisi dan menggunakan bahasa Jawa Kuno. Bila tidak, maka kakawin itu disebut menyimpang dari konvensi bahasa kakawin. Kakawin Pralambang Bhasa Wawatekan ini merupakan satu-satunya kakawin yang menyimpang (kalau bisa disebut unik) bila dilihat dari konvensi bahasa kakawin. Sebab kakawin ini berisikan beberapa kata yang bukan tergolong ke dalam bahasa Jawa Kuno. Kata-kata tersebut berupa nama orang, seperti Wlanda, Michles, Endralas, Jakupman, dan Ibrahim.

\section{Contoh:}

Tan warnan lwirnya sâgara thêrra datêng ri tpi desia kotta, saprâptanyan akonkon dadati ya dalu wang citra karkodulu rwa,

agyan tekung mapangguh mapangguh twas ika ri sira sang nâta runan patirtan sigrâ konkon mandangeng Blanda tucapa ta datêng Endralas den Jakupman.

\section{Terjemahan:}

Tidak diceritakan prihal perjalanannya di laut, kini telah tiba di desa pinggir kota.

Ketika mereka datang diperintahkan untuk menjemputnya lebih dulu dengan beriringan berdua.

Sekejap telah berjumpalah mereka dengan sribaginda raja yang ada di sebelah atas kolam permandian.

Segera disuruh menemui Belanda, dan diceritakan Endralas dan Jakupman telah datang.

Selain itu, kakawin ini punya kelainan pada manggalanya. Kakawin umumnya mengisi manggala dengan ucapan pemujaan pada dewa pelindung atau dewa yang disembahnya. Tetapai kakawin ini berisikan pujian kepada roh leluhur (ayah dan kakeknya) yang telah meninggal. Tidak adanya dewa pelindung dari kakawin ini, menunjukkan kesamaan dengan kakawin Ramayana yang juga tidak memuat dewa pelindung. Untuk jelasnya akan dikemukakan contoh manggala yang terdapat dalam Kakawin Pralambang Bhasa Wawatekan, seperti di bawah ini.

\section{Contoh:}

(a) Sajňa śrī naranâta sang lumaha ring rana sabha dadi sūksma dewattha, tinghal teki larangku denta kawkas kumlak ni panas nikang hati, göngning duhka sabhūr bhuwah swah angbêk ring hati puhara tibra mohita, Guntur kung kawangan larâmbêk atmah lelö apuhara mūrccita anglara.

(b) Ah nding nggânya pametanangku sawawâ pangupama ni larangku sâdrasa,

Sâksât sâgara bahni parwwata sumêk ri hati pamanasing lara angliput, 
Mwang yan tan hana sihta rakwa masiheng hulun amarêni pañcaning hati, âh ndin tan lwang I jiwaning wang apan kita makadha siheng hulun tuhan.

\section{Terjemahan:}

(1) Daulat tuanku raja yang telah gugur di medan laga, dan telah menggaib berwujud dewata.

Lihatlah kini kesedihan hamba karena baginda tinggalkan menahan sakit hati.

Besarnya kesedihan hamba sebesar jagat raya yang memenuhi perasaan, dan menyebabkan bingung tidak sadarkan diri.

Ditindih oleh gunung kesedihan, dihanyutkan perasaan nestapa yang menyebabkan lunglai, pinsan kesakitan.

(2) Ah, di manakah beliau bisa ku cari untuk kujadikan contoh perumpamaan tentang kesedihan yang kuderita dalam enam rasa.

Bagai lautan api yang menggunung memenuhi pikiranku yang menyebabkan terselimuti kesedihan.

Bila tiada kemurahan paduka mengasihi hamba yang akan mampu menghapus kegelisahan hati hamba.

Ah, mana mungkin hamba tidak akan mati bila tidak baginda kasihi.

Melihat manggala kakawin di atas, jelas tidak ada menyebutkan dewa pelindung atau dewa yang memberi anugerah sehingga mendapat keberhasilan dalam mengarang. Hal lain yang juga merupakan keunikan adalah, tidak adanya epilog dalam kakawin itu.

\section{Contoh bait terakhir:}

Ri luyuk tikang wwang angusung gagawan ika anidra ring hni, akjêp kaweśa pangarip mata tatan inawen babandaran,

rika malwi oyaku janarwa tinmu kapitut manah lňok,

adawan kâtâa puri ikang stayageyu anurat huwus pjah.

\section{Terjemahan:}

Ketika orang-orang yang bertugas mengusung barang bawaan pada lesu, lalu mereka tidur dalam perjalanan.

Hanya sesaat saja sebagai penghilang kantuk mata, tidak hirau akan barang bawaan.

Ketika itu kembali mereka temukan dan meneruskan (membawanya) karena merasa bersalah.

Panjang bila diceritakan keadaan puri yang kacau, secepatnya menulis tentang yang telah meninggal.

Melihat contoh kutipan di atas maka dapat diketetahui bahwa Kakawin Pralambang Bhasa Wawatekan tidak berisi manggala dan epilog. Kakawin tersebut berupa karya bersama dari Dewa Agung Istri Agung bersama ayah beliau yang wafat di Loji. Kemudian dilanjutkan oleh murid beliau dengan menggunakan bentuk kidung. Jadi berupa karya bertiga.

Bertolak dari uraian mengenai Kakawin Pralambang Bhasa Wawatekan seperti tersebut diatas maka dapat dikatakan bahwa karya itu sangat baik dan unik.

\section{(3). Kakawin Prêtu Wijaya atau Kakawin Brahmandha Purana.}

Kakawin ini mengisahkan tentang seorang raja yang bernama Wena memerintah dengan sangat kejam dan melarang rakyatnya beribadah. Keadaan itu menyebabkan para resi menjadi murka. Para resi kemudian bersatu memerangi raja Wena. Dewa mengatakan bahwa raja Wena tidak bisa dikalahkan kecuali oleh anaknya sendiri yang keluar dari lengan sang raja. Untuk itu para resi diberi petunjuk untuk memukul lengan sang raja.

Dalam peperangan para resi berusaha memukul lengan kanan raja Wena. Setelah lengan kanannya dipukul maka keluarlah seorang bayi, yang begitu lahir dengan cepat menjadi besar/ dewasa. Anak raja Wena itu diberi nama Prêtu. Priêtu disuruh oleh para resi melawan raja Wena. Akhirnya Pṛêtu dapat dapat membunuh raja Wena. Karena kemenangan itu ia dinamai Pṛêtu Wijaya.

Setelah matinya raja Wena, ceritera dilanjutkan dengan turunnya Dewi Pretiwi ke bumi untuk memberikan kebahagiaan ke pada umat manusia. Selanjutnya ceritera dilanjutkan dengan pemandangan yang indah-indah yang dihiasi dengan warna warni busana. Busana yang digunakan disesuaikan menurut tempatnya seperti: 
timur berwarna putih, selatan berwarna merah, barat berwarna kuning, utara berwarna hitam, dan di tengah berwarna campuran/panca warna (bhusana ider buwana).

Kakawin Brahmandha Purana ini sebenarnya dikarang oleh Anak Agung Pameregan atas petunjuk dari Dewa Agung Istri Kanya yang waktu itu sudah sangat tua (wis weddha, alius akisut carmania apan sering mopawasa). Ungkapan itu tercantum dalam bait awal kakawinnya.

\section{(4). Tutur Biksu Pungu.}

Karya ini agak pendek, berbentuk prosa, tidak bernarasi, dan monolog. Seluruh isi ceritera menceritakan tentang perbuatan yang boleh dilakukan bagi orang suci, bagi orang yang ingin mempelajari kawikun atau ingin menjadi resi atau pendeta. Jadi seluruhnya berisikan pendidikan kasanthikan / karakter.

\section{(5). Kakawin Irawantaka}

Kakawin ini merupakan karya yang paling panjang dari semua karya beliau. Kakawin ini menceritakan kisah lahirnya Sang Erawan. Erawan adalah putra dari Arjuna yang kawin dengan Dewi Ulupui. Erawan akhirnya terbunuh dalam perang besar Bharatayuddha. Ia dibunuh oleh Kala Srenggi yang kemudian dibunuh pula oleh Arjuna.

\section{(6) Kakawin Astikayana}

Kakawin ini terdiri atas 22 pesalinan (pergantian wirama). Dikutip dari kitab Adiparwa yang digubah menjadi kakawin berjudul $\mathrm{Ka}$ kawin Astikayana. Kakawin ini menceritakan perjalanan sang Astika. Juga mengenai pemuteran lautan susu agar tirta amerta ke luar. Para dewa dan para asura/raksasa bersama-sama melakukan pemuteran gunung mandara yang di dialasi oleh kura-kura yang dililit naga. Juga mengisahkan terjadinya gerhana bulan dan matahari. Kemudian ceritera dilanjutkan dengan kisah sang Garuda putra Dewi Winata, menjaga sang ular anak-anak dari Dewi Kadru. Pada akhirnya sang garuda dijadikan tunggangan dewa Wisnu.

Kakawin Astikayana selesai ditulis pada tahun Saka 1773 atau tahun masehi 1851. Hal ini diketahui dari tahun sangkalan yang ada pada pesalinan ke 24, bait ke 3 dan 4
Nahan donkwa mangun palambang aharep tumiru tiru ri sang kawiswara Wetning harsa tuhanku sang panikelan tanah angawi palambanging yasa Akweh rakwa palambang arddha mapened kahaturaken I jöng nareswara.. Barryan ratri guritnireki winiweka winaca waca de muniwara.

Praptang kartika masa rakwa hana matra manahing hati muda mengêta, Paksâmilwa mangun palambang amurang murang atisaya tan panut karma, rehning ngwang kinas an masan marêk I jöngnira ya karananing giragyasen, Kewalya hana matra kampita ri jöngnira sapala subakti tan kasaha.

Nangkan Palguna masa kepwan ing ulah kapetengan I hatingku tan sipi.

Ewuhning tiga sapta pandhita tununggalaken I rasan ing tri kayika,

Dening raja tama pwa wredya halaning manakuha kawi muda duryasa

Yan tan sang wiku sida wakya kadi landeping asurasaning manah licin.

\section{Terjemahan:}

Begitulah tujuanku mengarang kakawin bermaksud meniru karya sang pujangga besar.

Oleh sebabab kemauan junjunganku si penguasa Negara untuk berkarya mengarang kakawin.

Banyaklah kakawin tulisanku yang kurang bagus yang kuhaturkan kepada baginda ratu

Oleh karena setiap malam kakawin ini ditulis oleh yang diputrakan lalu dibaca oleh sang pendeta.

Sampailah pada bulan Kartika (September-Oktober), ada sedikit perasaan sadar akan kebodohan

Berniat ikut mengarang kakawin namun ngelantur tidak sesuai dengan konvensi kakawin

Sebab hamba sebentar-sebentar diperintahkan untuk menghadap beliau, nah hal itulah yang menyebabkan sperti tergesagesa

Tetapi adalah sedikit kegundahan hati di 
hadapan beliau agar berhasil berbakti dan tidak berpisah

Waktu bulan Palguna (ke 8/Januari-Februari) aku bingung untuk bertindak sebab pikiranku sangat gelap

bingung oleh tiga sapta pandita $(3,7,7)$, yang dipersatukan (1) oleh panglong ke 3 Karena raja bijak dan kaya namun pikiranku hanyalah pengarang kecil tanpa jasa/karya

Bila bukan pendeta sida wakya (berhasil segala ucapannya) bagai ketajaman (Landep) asura (raksasa) hati yang tulus.

Bila penafsiran ini benar seperti terjemahan di atas maka dapat dikatakan bahwa kakawin Astikayana selesai dikarang mulai bulan September-Oktober, sampai pada bulan (JanuariFebruari, tahun saka 1773 atau tahun 1851 Masehi. Tepatnya pada wuku Landep, asta waranya Sri. Sapta waranya Senen, Dasa waranya Raksasa.

\section{(7) Geguritan Dasa Pandawa.}

Karya ini mengggunakan tembang/pupuh macapat. Mengisahkan perjalanan Pandawa Lima, yaitu Yudistira, Bimasena, Arjuna, Nakula, dan Sahadewa.. Pandawa lima memiliki kembaran/saudara yaitu Panca Atma yang berkuasa di kerajaan Suniantara. Terjadi perang antara Pandawa melawan Pancaatma. Pancaatma kalah tetapi tidak dibunuh oleh Pandawa. Mereka tahu bahwa mereka masih bersaudara dan akhirnya mereka menyatu menjadi Pandawa lima. Ini kemungkinan bisa disebut sebagai penyatuan raga dan batin atau pisik dengan roh.

\section{(8). Karya-karya lain}

Ada tiga karya lain dari Dewa Agung Istri Kania. Karya yang dimaksud yaitu: Kakawin Astikayâna menceritakan perjalanan Sang Astika. Kakawin Sakraprajaya menceritakan kalhnya dewa Indra oleh anak Rahwana (Indra Jit), dan Bhaka Bûmi merupakan karya berbentuk prosa, yang mengisahkan tentang raja Bhaka.

Ada anggapan (diperlukan penelitian lebih lanjut) bahwa beliau juga melahirkan beberapa karangan. Dalam bentuk tutur yaitu Gohya Wijaya Dyatmika dan Pawana Ginegö. Dalam bentuk kidung yaitu Kidung Wargasari (versi Ida ratu saking luhur) yang sampai saat ini masih dikidungkan oleh masyarakat Bali. Kidung tersebut berbeda dengan Kidung Wargasari yang menggunakan pupuh Asti. Walau pun kebenarannya belum bisa dipastikan, tetapi warga desa Sangkanbuana Klungkung percaya bahwa kidung tersebut merupakan buah pikiran beliau (yoga sang Kawi). Tentu saja pernyataan itu memerlukan penelitian yang lebih matang.

\section{PENUTUP}

Paham pergerakan perempuan dalam dunia sastra klasik di Bali dikenal dengan munculnya seorang pengarang wanita yang sekaligus merupakan pejuang dalam melawan intervensi Belanda. Tokoh yang dimaksud adalah Ida I Dewa Agung Istri Kania. Lewat pikiran kritis dan "langõ" beliau lahir beberapa karya, baik karya sendiri maupun karya bersama dengan murid beliau. Karya-karya beliau berupa kakawin, kidung, geguritan dan tutur. Salah satu karya beliau yang terkenal adalah Kakawin Pralambang Bhasa Wewatekan. Kakawin itu menceritakan tentang: upacara pembakaran mayat (Patiwa-tiwa dan Baligya), gambaran kedatangan dan perang melawan Belanda di Kusamba Klungkung, sumpah kesepakatan kerjasama antara Klungkung, Gianyar, Bangli, dan Payangan, dan masih ada lagi beberapa kisah faktual yang terjadi baik di Kusamba, di Sweta Lombok, di Tabanan, dan di Klungkung.

Menariknya kepengarangan Ida I Dewa Agung Istri Kania dikaji berdasarkan sosiologi sastra, tentu sangat bermanfaat bagi generasi kini dan mendatang, setidaknya dalam lingkup Bali. Masyarakat Bali akan lebih merasa bangga memiliki seorang pahlawan, raja, yang sekaligus berprofesi sebagai pujangga klasik. Beliau merupakan sosok cermin, panutan atau suri tauladan anak bangsa khususnya generasi muda wanita Bali. Dewa Agung Istri Kania adalah raja wanita, pejuang dan seorang pujangga keturunan ningrat. "Yoga" beliau merupakan ciri feminisme yang lahir di Klungkung abad ke XIX. 


\section{DAFTAR PUSTAKA}

Barry, Peter. 2010. Beginning Theory. Yogyakarta; Jala Sutra.

Barry, Peter. 1987 (ed). Issu in Contenporary Critical Theory. Mac Milan Casebook.

Endraswara, Suwardi. 2013. Metodologi Kritik Sastra Yogyakarta; Penerbit Ombak

Oostindie, Gert. 2016. Serdadu Belanda Di Indonesia 1945-1950 (terjemahan Susi Moeimam dkk).

Jakarta. Yayasan Pustaka Obor

Putra, Ida Bagus Rai. 2009. Babad Dalem. Denpasar. Percetakan Bali.

Sugihastuti. 2002. Teori dan Apresiasi Sastra. Yogyakarta; Pustaka Pelajar.

Zoutmulder, P.J. 2000. "Kamus Bahasa Jawa Kuna-Indonesia”. Jakarta; Jambatan.

Naskah-Naskah yang digunakan

Bhaka Bhumi.

Geguritan Dasa Pandawa.

Gohya Wijaya Datmika.

Kakawin Astikayana.

Kakawin Bhasa Wewatekan.

Kakawin Irawantaka.

Tutur Biksu Pungu.

Kidung Wargasari.

Kakawin Brahmandha Purana (Pretu Wijaya). 